International Journal of Instruction e-ISSN: 1308-1470 • www.e-iji.net

Article submission code: 2020103114175

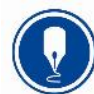

October $2021 \bullet$ Vol.14, No.4

p-ISSN: 1694-609X

pp. $103-118$

Received: $31 / 10 / 2020$

Revision: 22/02/2021
Accepted: 20/03/2021

OnlineFirst: 08/07/2021

\title{
Impact of Instructional Sequence to Teach Argumentative Writing to Disadvantaged Students Using the Opinion Article
}

Blanca Araceli Rodriguez-Hernandez

Facultad de Psicologia, Universidad Autonoma de San Luis Potosi, Mexico, araceli.rodriguez@uaslp.mx

Gabriela Silva-Maceda

Corresponding autor, Facultad de Psicologia, Universidad Autonoma de San Luis Potosi, Mexico, gabriela.silva@uaslp.mx

Written argumentation is a complex skill to master. It can be assumed that students can transfer oral argumentation skills into a written format. Still, students from disadvantaged backgrounds for whom this task is highly novel require greater scaffolding to formulate persuasive arguments in writing. Therefore, there is a need for developing sound methodologies to introduce argumentative writing to these students. This study's objective was to address this need to develop evidence-based methodologies for teaching genre novice students at the end of primary school in Mexico (5th and 6th grades). Based on a socio-discursive interactionist approach, an introductory instructional sequence using the opinion article was designed for disadvantaged students. A quantitative pre-test-post-test design evaluated its efficacy in fifth and sixth graders $(n=50)$ from a rural community in northerncentral Mexico by prompting an initial and final opinion article and measuring intervention changes with inferential statistics. Findings from a mixed $2 \times 2$ analysis of variance with Grade as the between-participants variable and Time as the within-participants variable suggested there was a significant instruction effect for both $5^{\text {th }}$ and $6^{\text {th }}$-grade groups (main effect of Time: $(F(1,48)=28.52, p=\leq .0001$, $\eta^{2} \mathrm{p}=.37$ ). Students did not significantly differ by grade level (main effect of Grade: $\left.F(1,48)=1.82, p=.18, \eta^{2}{ }_{p}=.03\right)$, nor did they benefit differently from the intervention (interaction of Time X Grade: $\left(F(1,48)=1.24, p=.27, \eta^{2} \mathrm{p}=.02\right)$. When examining the opinion article's dimensions, the Wilcoxon signed-rank tests revealed students could improve the structure and linguistic devices, but not the communication of their texts' purpose. Results suggest a brief, socially relevant opinion article instructional sequence can facilitate the learning of argumentative writing elements in genre novice rural students.

Keywords: argumentation, opinion article, writing, disadvantaged students, educational intervention, elementary education 


\section{INTRODUCTION}

Learning how to argue in writing is more complicated than a simple transfer of oral arguments into written ones. It involves the student's knowledge about writing, applying strategic behaviors, and the mastery of skills (Wijekumar, Graham, Harris, Lei, Barkel, Aitken, et al., 2019).

The elementary school curriculum in the United States and other parts of the world has incorporated argumentative reading and writing (Newell, Beach, Smith \& Van Der Heide, 2011). A body of research supports that argumentative reading and writing skills are critical for academic success (Newell et al., 2011; Nippold \& Ward-Lonergan, 2010). Therefore, its inclusion into school curricula has become particularly important to teach students the formal use of written language. In the American curriculum, the Common Core Standards include argumentative speech from preschool, when students are expected to express a written opinion or preference for a topic or book. Then the standards grow gradually until $5^{\text {th }}$ grade, where they include elements of text structure and coherence between an opinion and the reasons to support it. Finally, in $6^{\text {th }}$ grade, it is expected that students go beyond the written expression of such opinion to constructing an argument by supporting claims with clear reasons and relevant evidence.

However, there are many instances when students arrive in $6^{\text {th }}$ grade without explicit teaching of argumentative writing, as is the case for students from disadvantaged backgrounds in countries without a gradual curricular design. For these students, the task becomes even more challenging. They are the ones that most require developing written argumentation to navigate civic life on behalf of their communities and safeguard their rights (Powell, Cantrell, \& Adams, 2001). The present paper presents the evaluation of an instructional sequence designed to address the needs of these students.

\section{Review of Literature}

\section{Literacy gaps in disadvantaged students}

There are documented gaps in literacy for certain groups of students due to social or socioeconomic circumstances, such as being in a lower socioeconomic status (SES; Sirin, 2005), speaking another language (Han, 2012), or having a different dialectal variation of the majority language (Charity, Scarborough, \& Griffin, 2004). Moreover, a country's economic conditions are associated with the percentage of students who achieved a Level 2 or lower reading score in the Program for International Student Assessment (PISA) (Willms, 2018). Students from disadvantaged backgrounds show lower language growth indicators (Schwab \& Lew-Williams, 2016) and have less access to technology (Livingstone, Haddon, Gorzig \& Olafsson, 2011). They are also exposed to different sources of environmental stressors (Boyce, Sokolowski \& Robinson, 2012) and tend to have lower retention and lower higher-education participation rates (Entwisle, Alexander \& Olson, 2005).

Literacy difficulties are compounded when analyzing data from students in developing countries living in a low socioeconomic context. In Mexico, where the present study is carried out, students' scores in language and communication skills are closely related to their community's marginalization level: national assessment scores are lower for 
marginalized areas (INEE, 2017). Similarly, the town or city's population size was also associated with performance in the national assessment scores favoring cities over rural populations (INEE, 2017). These results show that high-marginalization and rural students are more likely to be at risk for lower literacy learning.

Given this context of significant gaps in performance, the importance of argumentative writing skills for academic success and adult civic life, a need in the literature was identified for instructional designs to develop the written argumentation skills in upper elementary students living in rural populations in developing countries. These students might not be exposed to arguments in written texts, to lay an evidence-based foundation with specific instruction implications for these kinds of students.

\section{Argumentative writing research: theory and empirical results}

Numerous studies have focused on identifying the best teaching practices to fulfill learning objectives in argumentative writing. A comprehensive review of the teaching and learning of argumentation literature (Newell et al., 2011) identifies two dominant research perspectives for the study of argumentation: cognitive and social. On the one hand, the cognitive perspective analyzes writers' cognitive processing models (MacArthur \& Graham, 2016). On the other hand, studies based on the social framework recognize argumentative reading and writing in the language used in rhetorical contexts or literacy events (Bazerman, 2016). This second subgroup of studies is strongly related to sociocultural reading and writing theories, which encourage researchers to "seek to understand how culturally and historically situated meanings are constructed, reconstructed, and transformed through social mediation" (Newell et al., 2011, p. 276).

There is a vast body of research for writing in general (meta-analyses by Graham, Capizzi, Harris, Hebert \& Morphy, 2014; Graham, McKeown, Kiuhara \& Harris, 2012; Graham \& Perin, 2007), and a smaller but still varied body of knowledge for argumentative writing (Ferretti \& Graham, 2019). There is less evidence for argumentative writing interventions in 4th, 5th and 6th-grade students (Ferretti, Lewis \& Andreus-Weckerly, 2009; Graham, MacArthur, Schwartz \& Page-Voth, 1992). A few recent studies focused on teaching oral argumentation in these age ranges (CervantesBarraza, Cabañas-Sánchez \& Reid, 2019; Evagorou, Nicolaou \& Lymbouridou, 2020). However, none of the argumentative studies in these age groups were performed with socially disadvantaged student populations or developing countries.

Most argumentative writing intervention studies are developed from the problemsolving learning framework or the pragma-dialectic theory of argumentation. These frameworks assume the previous teaching of argumentative writing; therefore, they are focused on improving the quality and diversity of students' argumentative skills. Two recent studies from a cognitive perspective have studied argumentative writing in disadvantaged populations in the USA a small-scale intervention study of struggling $4^{\text {th }}$ and $5^{\text {th }}$-grade writers (Harris, Ray, Graham \& Houston, 2019) and a large-scale intervention study of disadvantaged $3^{\text {rd }}, 4^{\text {th }}$, and $5^{\text {th }}$-grade students (McKeown, FitzPatrick, Brown, Brindle, Owens, \& Hendrick, 2019). Both studies use an 
intervention known as Self-Regulated Strategy Development (or SRSD; Harris \& Graham, 2017), which integrates explicit instruction in writing, self-regulation skills, and genre knowledge. The large-scale study was able to find an effect of the SRSD intervention on writing scores using a holistic and an analytic measure. Although this specific program has not been evaluated in other countries, self-regulation has been found to be critical for writing for all types of learners in Indonesia (Pionera, Degeng, Widiati \& Setyosari, 2020).

In contrast, two other theoretical frameworks only assume oral argumentation knowledge: the dialogic perspective and socio-discursive interactionism. These two theoretical frameworks share an instructional premise and a strategy: they recognize students' previous knowledge about oral argumentation and propose topics relevant to the students' contexts as discussion starting points. These frameworks are methodologically similar to general social models of teaching, such as the Role Playing and Jurisprudence models (Joyce and Weil, 2003). In these broad models, students assume a role to solve a case around a socially relevant situation to generate controversy and facilitate a position's adoption. However, the dialogic perspective of argumentation and socio-discursive interactionism frameworks have been used explicitly for argumentative writing. In sum, both frameworks take the students' language as input for teaching more complex content. In principle, these two theoretical frameworks could be used for teaching students who had not been previously taught writing arguments.

The dialogic perspective study by Reznitskaya, Anderson \& Kuo (2007) assumes that the argumentative schema is acquired by using it in social interactions or dialogue, such as group discussions about dilemmas in stories, where students take a position and defend it. They have shown these strategies help fifth-grade students to write significantly more argument-relevant propositions than control students. Meanwhile, Dolz's (1996) socio-discursive interactionism study focuses on text genre, and it uses oral argumentation to scaffold learning towards written argumentation. Therefore, it was considered ideal for disadvantaged students in developing countries who have not yet received explicit instruction on either argumentative writing or genre.

\section{Theoretical Framework for Instructional Design}

Socio-discursive interactionism (Bronckart, 2007) was selected for the present study. In addition to being used in Latin American contexts, this framework can be better adapted for an instructional design that assumes no previous familiarity with written argumentation. This framework also explains how communicative practices can transfer into written language resources: students are taught to produce authentic texts for improving known daily-life written genres and for introducing and refining those belonging to formal written language (e.g., essays, opinion articles). It also includes genre as teaching content. Another advantage of this framework is that it integrates teaching the grammatical aspects of language, which have been neglected in Mexico's national curricula, resulting in a lack of linguistic proficiency in students (Riestra, 2009). Finally, this framework involves the classroom teacher collaborating in the instructional design, which is relevant when teaching students inexperienced in written argumentation. 
Socio-discursive interactionism is an instructional framework focused on the relationships between the teacher, students, and language (Dolz, Gagnon \& Mosquera, 2009). Within the socio-discursive interactionist approach, genre is a specific communicative instrument produced in practice (Riestra, 2014). To facilitate learning genre, Riestra (2010) proposes a teaching sequence based on three dimensions: a genre's communicative purpose ("use" in the author's original studies), genre-specific linguistic devices ("form"), and structure to organize the text's content ("sense"). The purpose identifies the social use of the genre. The linguistic devices refer to the specific prepositions, conjunctions, adverbs, and textual organizers, among others, appropriate to the genre. The structure combines the particular genre's structure and text sequences (narrative, descriptive, explicative, and argumentative).

\section{The present study}

Using Riestra's dimensions, this study designed and implemented an introductory sequence to teach how to write an argumentative text to genre novice students in the last two primary school grades. The aim of this paper is to describe the efficacy of such an instructional sequence to teach argumentative writing to upper elementary students.

Unlike other studies and frameworks assuming an already basic grasp of the genre, the present research focuses on writing argumentation beginners. For this paper, we use the term genre novice students to refer to those who have not been exposed to arguments in written texts due to lack of exposure at home or lack of instruction at school. These students' needs require specific instructional strategies to help them understand the communicative purpose (the use of a text) and the dialogic nature of these discourse practices.

Therefore, the present study's objective is to address the need to develop evidence-based methodologies for teaching genre novice students at the end of primary school in Mexico, that is, 5th and 6th grades, by evaluating an instructional sequence specifically designed for these students.

Two research questions guided the present work:

a) What is the efficacy of an intervention grounded on socio-discursive interactionism on upper elementary genre novice students' opinion articles?

b) How do the dimensions of purpose, structure, and linguistic devices change in upper elementary genre novice students' opinion articles?

\section{METHOD}

This investigation was designed to evaluate an instructional sequence for teaching argumentative writing (an opinion article) to genre novice upper elementary students, using a quantitative one-group pre-test-post-test design (Mertens, 2014, p. 129). The "one-group" label of this design refers to the fact that there is no control group. However, the study did evaluate two different intervention groups, $5^{\text {th }}$ and $6^{\text {th }}$ grades, to examine potential differences between them. 


\section{Participants}

A public primary school was chosen to reflect the average rural or marginalized school's socioeconomic characteristics in the state of San Luis Potosi. It had an $8.6 \%$ of students performing at the satisfactory level or above on national tests (close to the state's rural schools of $6.2 \%$ and the state's higher marginalization schools of 7.7\%; INEE, 2019). The town has a population of 6,722 inhabitants, and its Marginalization Index (MI) of -.76 , reported by the Mexican National Statistics Institute (INEGI), indicated high marginalization (INEGI, 2010). The MI is an economic marker comprised of education, housing, and goods indicators for each minimal geographic area specified by the Mexican National Statistics Institute (INEGI) for census purposes (CONAPO, 2012).

The primary school had 540 students for the 2018-2019 school year in 15 groups, served by 18 teachers. There were two groups for each grade in upper elementary $\left(5^{\text {th }}\right.$ and $6^{\text {th }}$ grades). A classroom selection criterion was that teachers were willing and available to implement the instructional sequence. All students in $5^{\text {th }}$ grade section A $(\mathrm{n}=22)$ and $6^{\text {th }}$ grade section $B(n=28)$ participated in this study.

\section{Evaluation Instrument}

A review of existing and methodologically robust writing assessments in Spanish was carried out to identify a suitable measure. Although writing assessments exist in other languages, the search focused on Spanish instruments for the linguistic specificities. Some of the evaluation tools were designed for primary students (Atorresi, 2010) and high school (Gonzalez, 2014). However, none of these assessments aligned closely with the instructional sequence or the students' argumentative writing mastery level. Therefore, to evaluate initial and final texts, an instrument based on an opinion article, designed for foundational knowledge, and aligned with Riestra's dimensions was used: The Elementary Opinion Article Writing Assessment (Bautista, Espinoza \& Leal, 2019).

The instrument has 14 items covering three dimensions: Purpose, Structure, and Linguistic Devices, with a maximum score of 14 , one for each item. Two judges scored each text: the first author and a trained student. The student rater had previous experience in novice writers' text analysis and had trained in the evaluation instrument's theoretical and practical aspects. Pearson correlation coefficients as a measure of interrater reliability were considered good: $r=.963$ for the initial texts and $r=.961$ for the final ones.

\section{Writing prompt}

Initial and final texts were obtained and analyzed using the following writing prompt, designed according to the communication purpose in the opinion article and to the context and interests of the groups:

Sixth-grade students at the Benito Juarez school think that recess time is not enough to have lunch, play, and go to the restroom. For that reason, they want to convince the principal and the teachers at the school for recess to last 40 minutes instead of 30. What do you think? Would you like for recess to last longer? What would you say to the teachers and the principal to convince them? 
Help these children write an opinion article to convince the teachers and the principal to make recess last longer.

\section{Instruction Design}

For these students, the opinion article was chosen as the teaching content because it is evaluated but not taught in Mexico's curriculum (Rodriguez \& Martinez, 2018). The opinion article's purpose is to increase the acceptability of a controversial standpoint for the reader through the discussion topics that are known and essential to the intended audience, and for which the writer adopts a point of view. The instructional aim was to create written argumentative practices related to the students' immediate context based on findings that students are more likely to generate arguments about issues that directly affect their lives (Beach \& Doerr-Stevens, 2009).

The opinion articles' structure contains the following elements: presenting a statement, proposing arguments and counterarguments, and a conclusion. In this genre, in Spanish, an author generally uses the present tense and declarative sentences, a neutral voice, and linguistic devices to detach himself from the topic, such as nosotros [we]. However, while presenting the stance, the first person can be used as a point of view marker. Furthermore, logic-argumentative text organizers are used to link elements within the sentence (cause, opposition, and addition connectors to introduce arguments and counterarguments), and consequence or summary connectors to present conclusions.

The instructional design was created from the text genres instructional sequences proposed by Dolz and Schneuwly (1997). It was developed in collaboration with and implemented by the classroom teachers to align the topics and instructional activities with students' interests and learning practices. In total, the plan included 1160 -minutes sessions in three blocks, as shown in Table 1.

Table 1

Instructional sequence to teach writing an opinion article in upper elementary

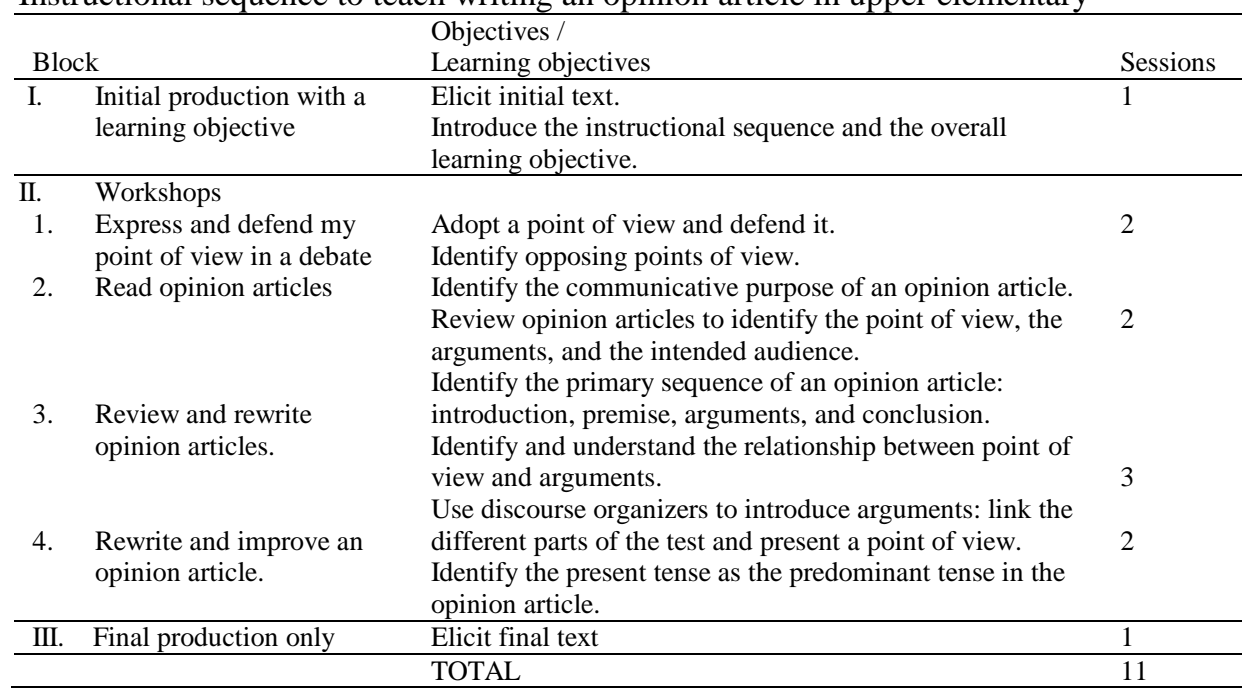


The first block (1 session) contained the writing prompt set up, which involved sharing the instructional sequence's learning objective with the students. The teacher introduced a daily-life issue to produce the initial text.

The second block ( 9 sessions) consisted of four instructional workshops, each delivered in several sessions. These contained the activities about the genre's communicative purpose and taught them to use different linguistic devices appropriate to the genre and structure or organize the text's content adequately. Daily life examples were introduced (school uniform, recess games, homework, etc.) for oral argumentation practice. Then, the teacher presented specific opinion articles as input for shared reading. Students were asked to identify, along with the teacher, the topic, the author's point of view, and supporting arguments. The taught writing process using text organizers to plan, write a draft, and use checklists for co- and self-evaluation.

Lastly, the third block (1 session) involved having the students produce the final text.

\section{Procedure}

The instructional sequence designed to develop the students' writing skills was implemented as planned. For the final texts, the same initial prompt was used to ask students to consider what they had learned in the workshops. It could be argued that in regular instruction conditions with students who regularly write for communication (not just transcribing text from the blackboard), using the same prompt might be considered a straightforward task and, therefore, an unreliable measure for the final text. However, for these genre novice students, even writing from the same prompt was extraordinarily complex and involved many novel processes they had tried in the workshops for the first time.

Even when teachers prompted students to produce a rewrite, the final text became a second writing piece: none of the students used the initial text as a first version; all of them created the last text from scratch. While unexpected, this allowed for a more rigorous evaluation of the efficacy of the intervention.

\section{FINDINGS}

The scores were analyzed using inferential tests, both for the Total Score and the three dimensions of Purpose, Structure, and Linguistic Devices, to identify whether the instructional sequence had the expected outcome of raising students' scores on the Elementary Opinion Article Writing Assessment.

\section{Total Score Effects by Grade Level}

Before analyzing the effects of the intervention by grade level, it was necessary to evaluate whether certain assumptions were satisfied in order to use parametric tests: the assumption of normality, not having univariate outliers, and the homogeneity of variance and covariance matrices.

To examine normality, skewness, and kurtosis were assessed for the total score in each $5^{\text {th }}$ and $6^{\text {th }}$ grade initial and final texts. The $z$-scores were obtained by dividing each value of the skewness statistic by its standard error (Field, 2013, p. 184). These analyses 
produced four skewness and four kurtosis $z$-scores. Results showed that only one of the eight $z$-scores was greater than 1.96 , significant at $p<.05$ : the initial $6^{\text {th }}$-grade texts had a significant skew (skew $z$-score $=2.11, p<.05$ ). Therefore, this subsample did not meet the assumptions of normality.

No univariate outliers were identified in any of the initial nor final texts grouped by each grade. Box's test of equality of covariance matrices was not significant (Box's $M=7.47, p$ $=.06$ ), suggesting this assumption was not violated. Levene's test for homogeneity of variances was not significant for the initial texts $(p=.54)$, suggesting the variances came from the same population; however, it was significant for the final ones $(p=.006)$, suggesting the variance differences were unlikely to have occurred by chance.

Given the size of the $6^{\text {th }}$-grade sample $(n=28)$, and the relative robustness of the $F$ test (Glass, Peckham \& Sanders, 1972), this parametric test was still chosen. Therefore, a mixed $2 \times 2$ ANOVA was carried out to evaluate whether the instructional sequence had had an impact on the students' scores and whether the two groups differentially received this hypothesized effect.

The within-participants variable Time had two levels: Initial text and Final text. The between-participants variable Grade also had two levels: 5th and 6th grade. The main question was the main effect of the variable Time to answer whether there was a significant intervention effect. The main effect of Grade is not as relevant because it distinguishes between $5^{\text {th }}$ and $6^{\text {th }}$ grade pooling the initial and final texts together, but it is reported, nonetheless. The interaction results would answer the question of whether the group trajectories are different.

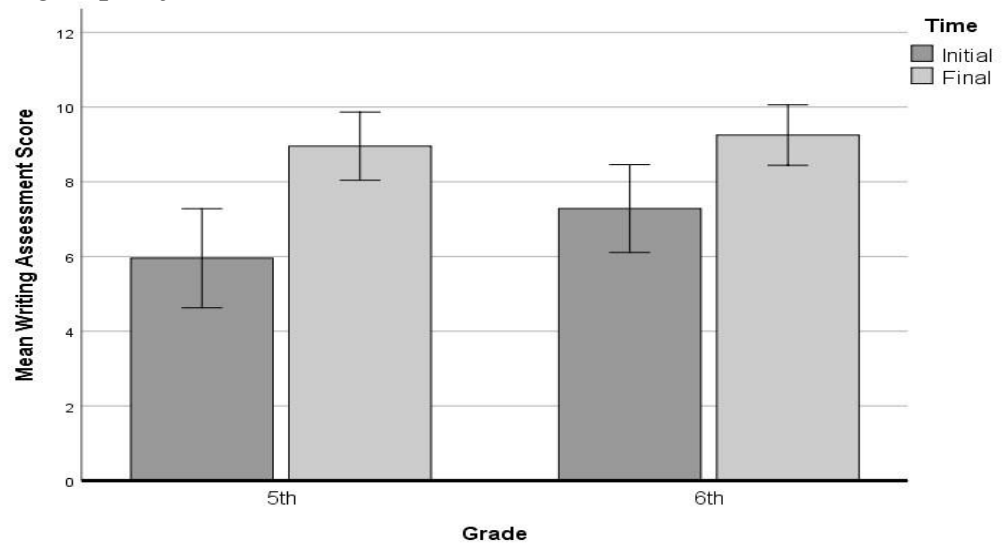

Figure 1

Mean total text score for initial and final texts by grade level. Error bars show $+/-2$ standard errors. The maximum score is 14

Answering the critical question of this study, the main effect of the within-participants variable Time was significant $F(1,48)=28.52, p=\leq .0001, \eta_{\mathrm{p}}^{2}=.37$, suggesting there was a change between initial and final scores when combining both grade levels. In contrast, the between-participants variable Grade's main effect was not significant 
$F(1,48)=1.82, p=.18, \eta_{\mathrm{p}}^{2}=.03$, suggests the two grades had equivalent writing performance when combining initial and final scores. Finally, the interaction between Grade and Time was not significantly different $F(1,48)=1.24, p=.27, \eta^{2} \mathrm{p}=.02$, suggesting the trajectories were similar for both grade levels, i.e., they benefitted similarly from the intervention. Figure 1 illustrates these results.

\section{Dimension Scores and Item Differences}

The previous analysis showed that only the variable Time remained significant for the Total score. Therefore, a repeated-measures test for mean differences was chosen to evaluate changes for each dimension and each item, pooling both 5th grade and 6th grade together, as they were statistically equivalent.

Skewness and kurtosis were evaluated this Time for each item score separated by initial and final texts using the same procedure outlined before. Most skewness and kurtosis $z$ scores were greater than $1.96(p<.05)$, meaning individual initial and final items had significant skewness, kurtosis, or both. Also, several univariate outliers were identified. Therefore, the non-parametric Wilcoxon signed-rank test was used to evaluate differences in individual items and dimensions between initial and final texts.

Table 2 shows the means and standard deviations of the subtotal scores for the three dimensions: Purpose, Structure, and Linguistic Devices. It also lists the $z$ coefficient for each Wilcoxon test, its significance, and its effect size using $r$.

Table 2

Initial and final scores on the three dimensions and their items for both groups $(n=50)$

\begin{tabular}{llllllll}
\hline & Initial scores & \multicolumn{2}{l}{ Final scores } & & \\
\hline & Mean & $S D$ & Mean & $S D$ & $z$ & $p$ & $r$ \\
\hline & & & & & & & \\
\hline Subtotal Purpose & 1.20 & .78 & 1.42 & .57 & -1.64 & 0.10 & -0.16 \\
\hline Item 1 Appeals to audience & .46 & .50 & .50 & .50 & -0.50 & 0.62 & -0.05 \\
\hline Item 2 Public good arguments & .70 & .46 & .92 & .27 & -2.67 & 0.01 & -0.27 \\
\hline Item 3 Considers opposing point of view & .04 & .19 & .00 & .00 & -1.41 & 0.16 & -0.14 \\
\hline & & & & & & & \\
\hline Subtotal Structure & 3.00 & 1.78 & 4.08 & 1.17 & -3.48 & $<0.001$ & -0.35 \\
\hline Item 4 Clear introduction & .70 & .46 & .86 & .35 & -1.89 & 0.06 & -0.19 \\
\hline Item 5 States point of view & .66 & .47 & .94 & .24 & -3.50 & $<0.001$ & -0.35 \\
\hline Item 6 Supportive arguments & .72 & .45 & .94 & .24 & -2.84 & 0.01 & -0.28 \\
\hline Item 7 Concedes or refutes opposing & .52 & .50 & .62 & .49 & -1.15 & 0.25 & -0.11 \\
point of view & .40 & .49 & .72 & .45 & -3.41 & $<0.001$ & -0.34 \\
\hline Item 8 Conclusion w/point of view & & & & & & & -0.46 \\
\hline Subtotal Linguistic devices & 2.50 & 1.26 & 3.62 & 1.00 & -4.58 & $<0.001$ & -0.45 \\
\hline Item 9 Present tense & .88 & .32 & 1.00 & .00 & -2.45 & 0.01 & -0.24 \\
\hline Item 10 Impersonal mode & .32 & .47 & .38 & .49 & -0.78 & 0.44 & -0.08 \\
\hline Item 11 Point of view markers & .40 & .49 & .78 & .41 & -4.15 & $<0.001$ & -0.41 \\
\hline Item 12 Causal connectors & .64 & .48 & .72 & .45 & -1.07 & 0.29 & -0.11 \\
\hline Item 13 Contrast connectors & .06 & .24 & .06 & .24 & 0.00 & 1.00 & 0.00 \\
\hline Item 14 Summary connectors & .20 & .40 & .68 & .47 & -4.71 & $<0.001$ & -0.47 \\
\hline
\end{tabular}

As shown in Table 2, the subtotal for the dimension Purpose was not significantly higher in the final texts. However, the item about the public good arguments significantly 
improved after the intervention. Remarkably, considering an opposing view decreased after the intervention, but this decline was not statistically significant. Meanwhile, the subtotal for the dimension Structure was, in fact, significantly higher in the final texts. This significant medium-sized difference $(r=-.35)$ was likely based on the considerable increase in the following items: children were more able, at the end of the intervention, to express their point of view, support it with specific arguments, and present a conclusion where the point of view was either restated or reformulated. Finally, the subtotal for the dimension Linguistic Devices was also significantly higher after the intervention, and the effect size was medium $(r=-.46)$. The items in this dimension that significantly increased were the use of present tense, point of view markers (such as "I think" or "I believe"), and sequence connectors.

\section{DISCUSSION}

This study's objective was to evaluate the impact of an instructional sequence designed to teach genre novice 5th and 6th graders how to write an opinion article. Since most previous studies focused on students with prior explicit knowledge of argumentation, this was an attempt to attend to disadvantaged students' needs in developing countries.

\section{Findings and relation to literature}

Inferential statistics on the Total score suggested the intervention significantly improved students' abilities in producing this specific genre, as measured by the initial and final texts. Moreover, this intervention did not have a statistically different effect in both groups: both benefitted equally from the intervention. However, in a more detailed analysis, there was variation in how each of the dimensions improved in the final texts: while the dimension Purpose was not significantly different at the end of the instructional sequence, Structure and Linguistic Devices were (both $p<.001$ ). In other words, students struggled to reveal the communicative purpose of their texts but could use the structural and linguistic elements learned in the workshops. Nonetheless, despite their inexperience with opinion article, the instructional design of using a social language practice from the students' daily life and a text genre as a teaching tool seems to have facilitated improvements in stating public good arguments, expressing their own point of view, offering supportive arguments, using point of view markers, and summary connectors. The design did not help with all dimensions equally: genre novice students still exhibited difficulties using contrast connectors and appealing to their audience even in their final texts.

The specific structural and linguistic improvements suggest that the intervention facilitated the transfer between the argumentation practice and the use of genre-specific linguistic resources. This knowledge acquisition falls in line with the expectations of the socio-discursive interactionism approach for these disadvantaged students. The lack of improvement in learning contrast connectors and appealing to an audience could be related to the complexities specific to argumentative writing (Dolz, 1996; Ferretti et al., 2009), or their lack of experience with this genre, as this was the first time the students were aware of opinion articles. The difficulty with the students' transfer from their dailylife language argumentation skills to the written ones could be related to the demands of writing or the instructional design. Another relevant aspect identified when prompting 
for the final text was that none of the students used the initial text for rewriting, despite the intervention teaching the writing process. This difficulty with the writing process could suggest that, for these students, writing means unloading their thoughts on paper without considerations to planning and revising, as perhaps these stages are not part of their writing notions.

Findings of a significant intervention effect are similar to previous intervention studies in upper elementary school children in facilitating the production of argumentative texts (Dolz, 1996; Ferretti et al., 2009; Harris et al., 2019; McKewon et al., 2019; Reznitskaya, Anderson \& Kuo, 2007). Although the Harris et al. (2019) and the McKewon et al. (2019) studies worked with disadvantaged students, all of these studies were assumed prior knowledge about argumentative writing, so they are not directly comparable to the present study's results where students lacked exposure to a gradual curricular design from previous grades. Therefore, this study contributes to the body of knowledge in effective teaching of written argumentation in an introductory fashion to a specific student population often overlooked: genre novice disadvantaged children in a developing country. This result was achieved using the sociodiscursive interactionism framework and genre as an instructional strategy, which allowed the creation of feasible learning objectives tailored for genre novice students. Given the importance of argumentative writing for academic success and their future civic life, that genre novice upper elementary grades can benefit from instruction tailored to them is a promising result. The findings also show that marginalized and rural students who had not been exposed to the opinion article could develop their written argumentation skills in Spanish. Moreover, they achieved this despite a double disadvantage: lagging in school performance and the lack of argumentative skills in their schools' curricular design.

\section{CONCLUSION}

Considering the brevity of the intervention and the complexity of producing argumentative writing, the results from the present intervention are encouraging for the following findings:

- The instructional design was likely successful in enhancing the quality of opinion articles in genre novice disadvantaged students.

- Genre novice students were able to enhance the structure and linguistic devices after working through this instructional design. They were unable to improve on the purpose of their opinion articles.

- Fifth and sixth graders benefitted equally from the instruction.

These results show how students in rural communities, with no prior exposure to the opinion article, could acquire some basis of argumentative writing to build upon with further instruction.

\section{RECOMMENDATIONS}

The study's findings reiterate guidelines already proposed for teaching genre novice writers. One, the selected topic must be controversial, relevant, and accessible, in the sense that children are able to argue from their own experience without needing further information (Newell et al., 2011), like the topic selected in the present study, expanding 
recess. Another recommendation is that the argument is included as teaching content since it is necessary to teach students how to argue and defend their perspectives (Dornbrack \& Dixon, 2014). Recommendations derived from the present study are: a) to include the explicit teaching of argumentative linguistic devices considering the students' previous knowledge; and b) to achieve the communicative purpose of the opinion article, the audience needs to be a known recipient to whom the students must direct their opinion; and c) to have students build their chosen communicative situations (cases) to argue for their interests and local concerns, similarly to other social models (Joyce \& Weil, 2003).

\section{LIMITATIONS}

Several methodological characteristics limit the generalizability of these findings. First, the sample size came from one school. Even when this study was designed to be preliminary, future work should include a control group and increase schools' sample size and diversity. Although considered representative of Mexican rural schools, the selected school could differ in other characteristics that could have influenced the degree of effectiveness found. Another methodological consideration is that the topic remained the same for the final texts, so it remains to be seen whether the students can transfer their new skills in the same genre but with a different yet still socially relevant topic.

\section{REFERENCES}

Atorresi, A. (2010). Escritura: un estudio de las habilidades de los estudiantes de América Latina y el Caribe. Santiago de Chile: Unesco, Oficina de Santiago.

Barton, D. (2007). Literacy: An introduction to the ecology of written language (2nd ed.). Malden, MA: Blackwell

Bautista, M., Espinosa, E. \& Leal, R. (2019). El aporte de la modelización de un género textual a la enseñanza del españolen la escolaridad primaria. XI Congreso latinoamericano para el desarrollo de la lectura y escritura (CONLES). Universidad Peruana Cayetano Heredia. Lima, Perú.

Bazerman, C. (2016). What do sociocultural studies of writing tell us about learning to write? In C. A. MacArthur, S. Graham, \& J. Fitzgerald (Eds.), Handbook of writing research (2nd ed.), 11-23.

NY: Guilford.

Beach, R., \& Doerr-Stevens, C. (2009). Learning argument practices through online role-play: Toward a rhetoric of significance and transformation. Journal of Adolescent $\&$ Adult Literacy, 52(6), 460-468.

Boyce, W. T., Sokolowski, M. B., \& Robinson, G. E. (2012). Toward a new biology of social adversity. Proceedings of the National Academy of Sciences, 109 (Supplement 2), 17143-17148

Bronckart, J. (2007). Desarrollo del lenguaje y didáctica de las lenguas. Buenos Aires: Miño y Dávila. 
Cervantes-Barraza, J., Cabañas-Sánchez, G., \& Reid, D. (2019). Complex Argumentation in Elementary School. PNA: Revista didáctica de la Matemática, 13(4), 221-246.

Charity, A. H., Scarborough, H. S., \& Griffin, D. M. (2004). Familiarity with school English in African American children and its relation to early reading achievement. Child Development, 75(5), 1340-1356.

CONAPO (2012). Indice de Marginación por localidad 2010: Capítulo 2. [PDF document]. Retrieved from: http://www.conapo.gob.mx/es/ CONAPO/Indice_de_Marginacion_por_Localidad_2010.

Dolz, J. (1996). Learning argumentative capacities. A study of the effects of a systematic and intensive teaching of argumentative discourse in 11-12-year-old children. Argumentation, 10(2), 227-251.

Dolz, J., Gagnon, R. \& Mosquera, S. (2009). La didáctica de las lenguas: una disciplina en proceso de construcción. Didáctica. Lengua y literatura, 21, 117-141.

Dolz, J. \& Schneuwly, B. (1997). Géneros y progresión en expresión oral y escrita. Elementos de reflexión a partir de una experiencia realizada en la Suiza francófona. Textos de didáctica de la lengua y de la literatura, (11), 77-98.

Dornbrack, J. \& Dixon, K. (2014). Towards a more explicit writing pedagogy: the complexity of teaching argumentative writing. Reading \& Writing, 5(1), 1-8.

Entwisle, D. R., Alexander, K. L., \& Olson, L. S. (2005). First grade and educational attainment by age 22: A new story. American Journal of Sociology, 110(5), 1458-150

Evagorou, M., Nicolaou, C., \& Lymbouridou, C. (2020). Modeling and Argumentation with Elementary School Students. Canadian Journal of Science, Mathematics and Technology Education, 20, 58-63.

Ferretti, R.P., Graham, S. (2019). Argumentative writing: theory, assessment, and instruction. Reading \& Writing, 32(6), 1345-1357.

Ferretti, R. P., Lewis, W. E., \& Andrews-Weckerly, S. (2009). Do goals affect the structure of students' argumentative writing strategies? Journal of Educational Psychology, 101, 577- 589.

Field, A. (2013). Discovering statistics using IBM SPSS Statistics, (4 ${ }^{\text {th }}$ edition). London: Sage.

Glass, G. V., Peckham, P. D., \& Sanders, J. R. (1972). Consequences of failure to meet assumptions underlying the fixed effects analyses of variance and covariance. Review of Educational Research, 42(3), 237-288.

Golder, C., \& Coirier, P. (1994). Argumentative text writing: Developmental trends. Discourse processes, 18(2), 187-210.

Gonzalez, R. (2014). Habilidades lingüísticas de los estudiantes de primer ingreso a las instituciones de educación superior. México, Distrito Federal: ANUIES. 
Graham, S., Capizzi, A., Harris, K. R., Hebert, M., \& Morphy, P. (2014). Teaching writing to middle school students: A national survey. Reading and Writing, 27(6), 10151042.

Graham, S., MacArthur, C. A., Schwartz, S., \& Page-Voth, V. (1992). Improving learning disabled students' compositions using a strategy involving product and process goal setting. Exceptional Children, 58, 322-334.

Graham, S., McKeown, D., Kiuhara, S., \& Harris, K. R. (2012). A meta-analysis of writing instruction for students in the elementary grades. Journal of Educational Psychology, 104(4), 879.

Graham, S., \& Perin, D. (2007). A meta-analysis of writing instruction for adolescent students. Journal of Educational Psychology, 99(3), 445.

Han, W. J. (2012). Bilingualism and academic achievement. Child Development, 83(1), 300-321.

Harris, K. R., \& Graham, S. (2017). Self-regulated strategy development: Theoretical bases, critical instructional elements, and future research. In R. Fidalgo, K. R. Harris, \& M. Braaksma (Eds.), Design principles for teaching effective writing: Theoretical and empirical grounded principles (119-151). Leiden: Brill.

Harris, K.R., Ray, A., Graham, S., \& Houston, J. (2019). Answering the challenge: SRSD instruction for close reading of text to write to persuade with 4th and 5th Grade students experiencing writing difficulties. Reading \& Writing, 32(6), 1459-1482.

INEE (2017). Informe de resultados PLANEA 2015. El aprendizaje de los alumnos de sexto de primaria y tercero de secundaria en México. Lenguaje y Comunicación y Matemáticas. México: INEE.

INEE (2019). Data from: Lenguaje y comunicación de $6^{\circ}$ de primaria [Language and communication in 6th grade; Dataset]. Digital Repository. Retrieved from https://www.inee.edu.mx/evaluaciones/planea/sexto-primaria-ciclo-2017-2018/

INEGI (2010). Sistema para la consulta de informacion censal 2010. [Interactive map]. Retrieved from: http://gaia.inegi.org.mx/scince2/ viewer.html

Joyce, B., \& Weil, M. (2003). Models of teaching. New Delhi: Prentice-Hall.

Livingstone, S., Haddon, L., Gorzig, A., \& Olafsson, K. (2011). Risks and safety on the internet: The perspective of European children: full findings and policy implications from the EU Kids Online survey of 9-16-year-olds and their parents in 25 countries. Retrieved from: http://eprints.lse.ac.uk/33731/1/Risks\%20and\%20safety\%20on\%20the \%20internet(lsero).pdf

MacArthur, C. A., \& Graham, S. (2016). Writing research from a cognitive perspective. In C. A. MacArthur, S. Graham, \& J. Fitzgerald (Eds.), Handbook of writing research (2nd ed.), 24-40). NY: Guilford.

McKeown, D., FitzPatrick, E., Brown, M., Brindle, M., Owens, J., \& Hendrick, R. (2019). Urban teachers' implementation of SRSD for persuasive writing following practice-based professional development: positive effects mediated by compromised fidelity. Reading \& Writing, 32(6), 1483-1506. 
Mertens, D. M. (2014). Research and evaluation in education and psychology: Integrating diversity with quantitative, qualitative, and mixed methods. London, UK: Sage Publications.

Newell, G., Beach, R., Smith, J. \& Van Der Heide, J. (2011). Teaching and learning argumentative reading writing: A review of research. Reading Research Quarterly, 46(3), 273-304.

Nippold, M. A., \& Ward-Lonergan, J. M. (2010). Argumentative writing in preadolescents: The role of verbal reasoning. Child Language Teaching and Therapy, 26(3), 238-248.

Pionera, M., Degeng, I., Widiati, U., \& Setyosari, P. (2020). Instructional Methods and Self-Regulated Learning in Writing. International Journal of Instruction, 13(3), 43-60.

Powell, R., Cantrell, S.C., \& Adams, S. (2001). Saving Black Mountain: The promise of critical literacy in a multicultural democracy. The Reading Teacher, 54, 772-781.

Reznitskaya, A., Anderson, R. \& Kuo, L. (2007). Teaching and learning argumentation. Elementary School Journal, 107, 449-472.

Riestra, D. (2009). Enseñar a razonar en lengua materna, las implicancias discursivas y textuales de la acción del lenguaje [Teaching reasoning in the first language, discourse and text implications on language actions]. Estudios Linguisticos, 3, 411-425.

Riestra, D. (2010). Didáctica de la lengua: la contribución al desarrollo de las capacidades discursivo- textuales. Cuadernos de la Facultad de Humanidades y Ciencias Sociales, 39, 191-206.

Riestra, D. (2014). Uso y formas de la lengua escrita. Reenseñar la escritura a los jóvenes. Un puente entre el secundario y la universidad. Buenos Aires, Argentina: Novedades educativas.

Rodriguez, B., \& Martinez, C. (2018). Analisis del uso de conectores discursivos en la argumentacion escrita de alumnos de primaria. Entreciencias. Diáalogos en la sociedad del conocimiento, 6(18), 93-107.

Schwab, J. F., \& Lew-Williams, C. (2016). Language learning, socioeconomic status, and child-directed speech. Wiley Interdisciplinary Reviews: Cognitive Science, 7(4), 264-275.

Sirin, S. R. (2005). Socioeconomic status and academic achievement: A meta-analytic review of research. Review of educational research, 75(3), 417-453.

Wijekumar, K., Graham, S., Harris, K., Lei, P., Barkel, A., Aitken, A., \& Houston, J. (2019). The roles of writing knowledge, motivation, strategic behaviors, and skills in predicting elementary students' persuasive writing from source material. Reading \& Writing, 32(6), 1431-1457.

Willms, J. D. (2018). Learning divides: Using monitoring data to inform educational policy. Information Paper No. 54. Montreal: UNESCO Institute for Statistics. Retrieved from: http://uis.unesco.org/sites/default/ files/documents/ip54-learning-divides-usingdata-inform-educational-policy.pdf 